\title{
MARKETING STRATEGIES OF ENTERPRISES IN UKRAINE RETAIL ELECTRONIC COMMERCE
}

\author{
Tetiana Dubovyk ${ }^{1}$, Iryna Gamova ${ }^{2}$, Yanina Lisun ${ }^{2}$ and Diana Fayvishenko ${ }^{2}$ \\ ${ }^{I}$ Doctor of Sciences, Professor \\ ${ }^{2}$ Ph.D., Associate Professor \\ Kyiv National University of Trade and Economics, 19, Kyoto str., 02156, Kyiv, Ukraine
}

\begin{abstract}
Marketing strategies of the retail e-commerce companies are the driving force behind the implementation of a set of dominant marketing principles and the choice of marketing tools to address the weaknesses of the enterprise. The main role played by the retailer's e-commerce company in choosing a marketing strategy consists of delivering the goals that must be achieved. Marketing strategies are divided into types depending on the timing of implementation, competitive advantages, the competitive position of the online company and its competitors, the competitiveness of the enterprise and the attractiveness of the market, the degree of market segmentation, the elements of the marketing complex, the state of the market demand etc. The retail e-commerce market is developing at a rapid pace, which has led to the emergence of new retail e-commerce participants and the use of hybrid marketing strategies. The chosen topic is a matter of high relevance due to the formation of new types of marketing strategies on the Internet according to the types of the retail e-commerce subjects, which are focused on the creation and maintenance of a sustainable competitive advantage. Various approaches to the development of a marketing strategy for the retail e-commerce companies allow you to analyze both the marketing indicators of enterprises in general and a specific marketing initiative, regardless of the sphere of economic activity. There are new business models within the Internet system formed under the influence of global changes in the retail trade, the intensification of industry competition and the speed of new achievements. An enterprise becomes competitive if its consumers participate in electronic trade. Competition from the production zone is concentrated in the sphere of services (products)' and consumption promotion.
\end{abstract}

\section{KEYWORDS}

Marketing Strategies, Retail e-Commerce, e-Commerce, Startup

\section{INTRODUCTION}

To date, Ukraine has passed through a phase of globalization that has embraced all spheres of life, including the online environment. In order to differentiate their products amongst others, the companies should correctly and competently carry out their strategic planning.

In the process of creating a marketing strategy, you need to consider the many factors of the online environment. The chosen topic is a matter of high relevance due to the formation of new types of marketing strategies on the Internet according to the types of the retail e-commerce subjects, which are focused on the creation and maintenance of a sustainable competitive advantage. Various approaches to the development of a marketing strategy for the retail e-commerce companies allow you to analyze both the marketing indicators of enterprises in general and a specific marketing initiative, regardless of the sphere of economic activity. There are new business models within the Internet system formed under the influence of global changes in the retail trade, the intensification of industry competition and the speed of new achievements. An enterprise becomes competitive if its consumers participate in electronic trade. Competition from the production zone is concentrated in the sphere of services (products)' and consumption promotion. 


\section{LITERATURE REVIEW}

The existing researches conducted by the domestic and foreign scholars are devoted to both theory and practice of the process of marketing strategy effectiveness' evaluation, as far as the enterprises in retail electronic commerce sphere are concerned.

The marketing field is becoming a competitive place, so a good and effective marketing strategy is needed in order to sell products and receive information about the consumer Internet preferences. Successful online activity requires not only a quality product, but also an effective marketing strategy. Most successful startups have a clear marketing strategy that helps them making their efforts more effective (Shuen, 2008).

It is clear that important strategic decisions primarily relate to the achievement of the business' marketing objectives - the intention to maintain the stability of the market share, stable profit growth and the achievement of benefits. Strategic marketing decisions also include the decisions related to the consumer attitudes in terms of quality assurance and the choice of appropriate prices (the annual price growth is at a lower level than in the industry). In addition, these decisions include the responsibilities before the workers (high salary, working conditions) and the population of the region (support for the employment, compliance with European standards). That is, it is necessary to foresee not only technological but also socio-economic changes and environmental factors' trends (Litovchenko, 2009).

Romanenko (2014) points out at the necessity of dividing the online marketing strategies in accordance with the goal, highlighting the tactics and the scope of use in the process. The author proposed five online marketing strategies: that of the information gathering, cost minimization, personal sales and re-sales.

It is important for startups to have a clear marketing strategy as a marketing strategy plays important role in the company's culture, products, services and pricing (The Ultimate Startup Marketing Strategy by Venture Harbour, 2015). The marketing of a successful startup requires you having both a great product and a good marketing strategy. (The Ultimate Startup Marketing Strategy by Venture Harbour, 2015). The feedback from early customers is very important for startups.

The question of analyzing marketing strategies of the retail electronic commerce companies in general from the point of view of marketing and the dynamics of consumer preferences in this industry in the world and in Ukraine needs further consideration, which indicates the relevance of the research.

\subsection{Marketing Strategies at the Retail E-Commerce Companies}

The strategy determines the path of the enterprise development in accordance with market requirements, orienting the enterprise towards the new ways of using capital, the innovative technological production processes and the effective forms of product market introduction. As a matter of fact, the company's strategy is a long-term document, a set of interconnected stages aimed at fulfilling certain goals.

For the purpose of studying the marketing strategies at the retail e-commerce companies, we conducted a survey among representatives of the Ukraine's retail e-commerce companies. 165 people participated in the study; 144 relevant questionnaires were selected for further analysis - that is, for those enterprises that carry out retail online commerce activities. Survey sample: owners (co-owners) of enterprises (25\%); senior management and top managers (22\%); private entrepreneurs (25\%); chief accountants / accounting personnel $(12 \%)$; middle-level managers $(16 \%)$. The vast majority of the retail e-commerce companies are small and medium-sized businesses, including Rozetka, Sokol, Comfi, Fotos, Modnakasta, Sportmarket, Meblishop, Profisport, Zoomagazin, Epicentr, Auto, Intimua and the social networking representatives: Facebook, Instagram, TilTok and others. According to the results of the survey, it was found that the vast majority of retail outlets are engaged in the marketing strategies development $(95 \%)$. The basis of the survey are the online stores $(45 \%)$ concentrated in Kyiv (34\%), for $41 \%$ of them the organizational-legal form constituted private entrepreneurs; engagement in the retail trade $(60 \%)$ : household and electrical engineering (18\%), computer technologies $(10 \%)$, diverse product groups $(11 \%)$, clothing, footwear, cosmetics, perfumery $(15 \%)$ with the online activity experience exceeding 5 years $(40 \%)$; the number of employees - up to 10 people $(27 \%) .85 \%$ of respondents indicated that there was no uniform classification of online marketing strategies and a lack of research in this area, which confirmed the relevance of the topic chosen for study in the article.

The authors developed a model for choosing a retail e-commerce company marketing strategy that would aggregate enterprise data based on benchmarking and SWOT analysis (see Table 1). The following is an 
estimate of the retail e-commerce companies operating on the market for at least 3 years. During the S-analysis, the following steps were taken:

- $\quad$ it has been established that the $\mathrm{P}$ index equals to: $\mathrm{P}_{1}-1 ; \mathrm{P}_{2}-2 ; \mathrm{P}_{3}-3 ; \mathrm{P}_{4}-4 ; \mathrm{P}_{5}-5$;

- the online stores have been selected that belong to the benchmark group (the five major online consumer electronics stores in Ukraine - Rozetka, Allo, Fotos, Mobilluck and Foxtrot (Forbes, 2018));

- $\quad$ the SWOT- analysis has been performed;

- $\quad$ we calculated the average weighted level of performance of the main functions by the Rozetka Internet store within the limits of the four marketing set components and the SWOT analysis results, as well as the average performance level for each of the functions, e.g., for the Rozetka online store.

Table 1. Evaluating the criteria for choosing a marketing strategies by the online Rozetka store (proposed by the authors)

\begin{tabular}{|c|c|c|c|c|c|c|c|c|c|}
\hline \multirow[b]{2}{*}{ Criterias } & \multicolumn{4}{|c|}{ Weight coefficient } & \multirow[t]{2}{*}{$\mathrm{P}_{1}$} & \multirow[t]{2}{*}{$\mathrm{P}_{2}$} & \multirow[t]{2}{*}{$\mathrm{P}_{3}$} & \multirow[t]{2}{*}{$\mathrm{P}_{4}$} & \multirow[t]{2}{*}{$\mathrm{P}_{5}$} \\
\hline & $\begin{array}{l}\text { Product } \\
\text { (1) }\end{array}$ & $\begin{array}{l}\text { Price } \\
(2)\end{array}$ & $\begin{array}{l}\text { Place } \\
(3)\end{array}$ & $\begin{array}{l}\text { Promotion } \\
\text { (4) }\end{array}$ & & & & & \\
\hline Number of tasks performed & 0,15 & 0,1 & 0,05 & 0,05 & $1,2,3,4$ & & & & \\
\hline $\begin{array}{l}\text { Level of the policy management functions } \\
\text { realization }\end{array}$ & 0,45 & 0,28 & 0,3 & 0,5 & & & & 1,2 & 3 \\
\hline Level of the macro-sized medium risks & 0,11 & 0,14 & 0,2 & 0,1 & & & 1,3 & 2,4 & \\
\hline Level of the macro-sized medium resources & 0,12 & 0,2 & 0,12 & 0,13 & & 3 & 4 & 1,2 & \\
\hline Level of the macro-sized medium deficiencies & 0,11 & 0,15 & 0,2 & 0,1 & & & $1,2,3$ & 4 & \\
\hline Level of the macro-sized medium advantages & 0,06 & 0,18 & 0,13 & 0,12 & & 3 & 4 & 1,2 & \\
\hline Total & 1 & 1 & 1 & 1 & & & & & \\
\hline $\mathrm{Ci}$ & $19 / 3,3$ & $22 / 4$ & $16 / 3,2$ & $20 / 4,1$ & & & & & \\
\hline
\end{tabular}

We found that the important research criterion is the following one: the level of implementation of the product policy management functions $(0.45)$, since the main task is to develop a product marketing strategy. The values of $\mathrm{Ci}$ calculated for the online stores are as follows: Allo - 2.7, Fotos - 2.4, Mobilluck - 1.8 and Foxtrot - 1.5.

The level of performance of the pricing policy management functions (0.28) is a determining factor in the formation of marketing pricing strategies. The index of $\mathrm{Ci}$ for the online stores is as follows: Allo - 3.5, Fotos - 3, Mobilluck - 1.9 and Foxtrot -1.

The level of implementation of the sales management functions $(0.28)$ in the online Rozetka store received the highest score - 5, as evidenced by a well-established marketing system. The $\mathrm{Ci}$ value for the online stores is as follows: Allo - 2.9, Fotos - 2.2, Mobilluck - 1.9 and Foxtrot - 1.9.

The level of performance of the promotion policies management $(0.5)$ in the online Rozetka store received the highest score -5 , as evidenced by a well-established advancement policy. The $\mathrm{Ci}$ index value for the online stores is as follows: Allo - 3.1, Fotos - 2.4, Mobilluck - 1.9 and Foxtrot - 0.9.

The number of tasks accomplished by the marketing product strategy has been unified to 1. Let's distribute the marketing product strategies by 3 ranks in accordance with the goals set:

I- aggressive marketing product strategies: market segmentation and enlargement of the market share; increasing sales volumes; product market expansion; changing product design; target audience segmentation; content updating; range of product planning (use of filters); range of product planning (use of filters).

II- progressive marketing product strategies: stable competitive position on the market; profit increase; improvement of the product consumer properties; selection of substitute and complementary products; introduction of new products to the market; suggesting product's importance to consumers; forming consumer understanding of inseparability of the product and the brand name.

III- supporting marketing product strategies: retaining leading positions on the market; development of new products; modifying some product groups; product line optimization; forming consumer tastes.

For the first rank of marketing product strategies the value of $\mathrm{Ci}$ ranges from 0.1 to 2; for the progressive marketing product strategies the value of $\mathrm{Ci}$ ranges from 2.1 to 3.9; and for the supporting marketing product strategies the value of $\mathrm{Ci}$ ranges from 4 to 5 . Thus, we have systematized the analysis indicators for the retail e-commerce companies and the implementation of marketing goals into one system. 
If the company distributes traditional goods, the prices are set lower than in the offline businesses; also, providing the free shipping is a big advantage. If the company offers unique products that can be purchased only in this place, then the reasonable strategy is to set maximum prices (the margin is more than 101\%).

One of the online pricing features constitutes the possibility of transferring part of the sold product value to another person (attracting advertisers). Taking the product marketing strategies as an example, let's evaluate the corresponding distribution of pricing strategies:

I- aggressive marketing pricing strategies: influencing consumers by pricing policies for individual groups of products; to increase profitability through high volumes of sales, with the reduced price markups taken into account; increasing the number of persistent consumers through financial rewards; formation of a financially stable enterprise in the mind of the consumers; locking the consumers in to the enterprise (discounts for persistent consumers); updating product range.

II- progressive marketing pricing strategies: enforcement of price changes; implementation of new special offers; ensuring price stabilization for competing products; raising product value (overrated product prices); ousting competitors; winning mass buyers.

III- supporting marketing pricing strategies: changing enterprise's pricing policy; emergence of the enterprise at a new price range; implementation of new price triggers (price leader at the market); decreasing inventories; forming a stable enterprise's image.

III. The marketing distribution strategies are based on the optimal choice of the product delivery scheme from the manufacturer to the consumer, from the supplier to the distributor and from the end selling enterprise to the consumer, and are directly affected by the marketing policy terms (transportation, storage, delivery of the product, etc.). (Misnik, 2011).

Let's see the allocation of marketing distribution strategies of the retail e-commerce companies in 3 ranks, in accordance with the marketing goals:

I- $\quad$ aggressive marketing distribution strategies: expansion of marketing channels; detection of consumer preferences; choosing agents or dealers; changing marketing channels; decreasing time necessary for product sales.

II- progressive marketing distribution strategies: optimizing marketing channels; expanding product distribution geography; finding new channels of product distribution; improving consumer service quality; marketing of products that are not in demand; implementation of a sales promotion system.

III- supporting marketing distribution strategies: seasonal product marketing; use of non-standard marketing channels (air delivery, the "same day" delivery); permanent marketing channels; maintenance services; convenient product purchase method; after-sales services.

IV. The marketing strategies of the retail e-commerce entities' promotion are an important tool of competition. The concept of promotion takes leading place in the Internet space; the marketing strategies are based on the creation of an effective system for managing consumer perceptions of both products and enterprises in general through the study of the online consumers' preferences and needs (Misnik, 2011).

The marketing policy of an online store promotion is a leader, a pioneer and covers $48 \%$ of the Ukrainian market, ranking 17 th in popularity in the country and $1766^{\text {th }}$ in the world. Let's see the distribution of marketing strategies for the retail e-commerce companies' promotion in 3 ranks, in accordance with the promotion goals:

I- aggressive marketing distribution strategies: implementation of the SEO and SMO optimization channels; promotion of related products through cross cooperation; increasing awareness about the enterprise or individual product lines; increasing the number of information channels used to communicate with consumers; maintaining consumer communications (attracting attention to the brand name).

II- progressive marketing distribution strategies: creation of a corporate identity; demonstrating the product's strong points; intensification of the existing capabilities and resources of the enterprise; increasing the marketing volumes and the market share of the enterprise without changing its product/market positions; expansion of other sector's customer base.

III- supporting marketing distribution strategi: formation of the brand's recognizability by consumers; associating the proprietary colors with the brand name; brand name plays the decisive role in product purchases; use of non-standard methods of promotion.

In order to maintain the leading position in the electronic market and to establish a sales system, it is necessary to apply a concrete and systematic approach to the promotion. The promotion of products is carried out through advertising, sales promotion, public relations (PR) campaigns, sales promotion or direct marketing. Advertising in the e-commerce is used as an information reporting tool for a comprehensive electronic product and enterprise. A false advertisement is a common problem in e-commerce. Also, very often you can see the 
feedback messages about the service or enterprise written by the employees of the enterprise. An intrusive and annoying mailing, SMS-mailing pose great problems and result in the loss of consumers. In order to prevent possible ethical problems in product promotion affecting consumers, business partners, suppliers and competitors, one should be guided by the principles of benevolence, honesty and integrity (Sana, 2009).

Indicators of the marketing strategies effectiveness should be calculated and monitored continuously. Positive dynamics from the implementation of strategies can become traceable after a while; it all depends on the chosen strategy.

1. Results of S-analysis and ranking of marketing strategies of TOP-5 retailers of Ukraine. Let's summarize the results of S-analysis and the ranking of marketing product strategies for the TOP-5 Ukrainian retailers (Table 2).

Table 2. Marketing Product Strategies of the TOP-5 Retail Electronic Commerce Companies of Ukraine (proposed by the authors)

\begin{tabular}{|c|c|c|}
\hline $\begin{array}{l}\text { Online } \\
\text { shops }\end{array}$ & $\begin{array}{c}\text { Marketing product } \\
\text { strategies }\end{array}$ & Product strategy peculiarities \\
\hline $\begin{array}{l}\text { Rozetka } \\
(3,3 ; \text { III })\end{array}$ & 1 - adaptation strategy; & $\begin{array}{l}1 \text { - changes of the outer appearance (packaging, design) of the product, with the } \\
\text { requirements of the online consumers taken into account; }\end{array}$ \\
\hline $\begin{array}{l}\text { Allo } \\
(2,7 ; \text { II })\end{array}$ & $\begin{array}{l}2 \text { - innovation strategy; } \\
1 \text { - niche penetration } \\
\text { strategy; } \\
2 \text { - relevance strategy; }\end{array}$ & $\begin{array}{l}2 \text { - use of non-standard (innovative) methods of product support } \\
1 \text { - this strategy is directed at acquiring the favor of a certain group of consumers; } \\
2 \text { - the strategy is directed towards a set of measures to achieve the necessary } \\
\text { levels of actualization among specialists and relevancy among consumers }\end{array}$ \\
\hline $\begin{array}{l}\text { Fotos } \\
(2,4 ; \text { II })\end{array}$ & $\begin{array}{l}1 \text { - motivation strategy; } \\
2 \text { - coordination strategy; }\end{array}$ & $\begin{array}{l}1 \text { - this strategy should arouse the desire among the online users to buy this } \\
\text { product; } \\
2 \text { - in its essence, this strategy aims at maximum conformity of the semantic } \\
\text { content to the material one }\end{array}$ \\
\hline $\begin{array}{l}\text { Mobilluck } \\
(1,8 ; \mathrm{I})\end{array}$ & $\begin{array}{l}1-\text { narrow specialization } \\
\text { strategy }\end{array}$ & $\begin{array}{l}1 \text { - users of the advanced technology products form small percentage of all the } \\
\text { community; therefore, the marketing product strategy should be concentrated in } \\
\text { accordance with this segment's preferences and needs }\end{array}$ \\
\hline $\begin{array}{l}\text { Foxtrot } \\
(1,5 ; \mathrm{I})\end{array}$ & $\begin{array}{l}1 \quad-\quad \text { consumer } \\
\text { individualization } \\
\text { strategy; } \\
2-\text { the "demand" strategy }\end{array}$ & $\begin{array}{l}1 \text { - this strategy is widely used by enterprises oriented at consumers' individual } \\
\text { orders; } \\
2 \text { - organizing prime presentations of the products; formalization of anticipatory } \\
\text { orders and creating product deficiencies that compel to purchase, as the } \\
\text { enterprise's key strategy }\end{array}$ \\
\hline
\end{tabular}

Consequently, taking into account the peculiarities of online products, we have developed the marketing product strategies. The proper application of marketing strategies in relation to the product policy is a functionally important component for the online business' success.

The rank gradation is given under Table 1; therefore, the further research will be based on the results of $\mathrm{S}$-analysis and the ranking of the TOP-5 marketing pricing strategies of the Ukrainian retail e-commerce companies (Table 3).

Table 3. Marketing pricing strategies of the TOP-5 retailers of Ukraine (proposed by the authors)

\begin{tabular}{|c|c|c|}
\hline $\begin{array}{c}\text { Online } \\
\text { shops }\end{array}$ & $\begin{array}{c}\text { Marketing pricing } \\
\text { strategies }\end{array}$ & Pricing strategy peculiarities \\
\hline $\begin{array}{l}\text { Rozetka } \\
\text { (4; III) }\end{array}$ & $\begin{array}{l}2 \text { - "cherry- } \\
\text { picking" strategy }\end{array}$ & $\begin{array}{l}1 \text { - provides for the establishment of high prices for the products that have unique } \\
\text { qualities. } \\
\text { In this segment, online consumers are characterized by low price sensitivity and are } \\
\text { guided by the factors of prestigiousness and usefulness; } \\
2 \text { - provides for the establishment of maximum high prices when entering the } \\
\text { e-commerce market with an essentially new product that has no counterparts. This } \\
\text { allows the seller to use its monopolistic position for some time, which maximizes } \\
\text { short-term profit through an increased rate of return }\end{array}$ \\
\hline $\begin{array}{l}\text { Allo } \\
(3,5 ; \text { III })\end{array}$ & $\begin{array}{l}1 \text { - deep } \\
\text { penetration } \\
\text { strategy; }\end{array}$ & $\begin{array}{l}1 \text { - characterized by proposing high quality products at medium prices; } \\
2 \text { - provides for the establishment of prices at an industry average or market average } \\
\text { level, or, at a higher than average level; the main goal of this strategy is to gain profit } \\
\text { in the long-term outlook. The strategy can be used at all stages of the product life cycle, } \\
\text { expect for the abatement stage }\end{array}$ \\
\hline
\end{tabular}




\begin{tabular}{|c|c|c|}
\hline & $\begin{array}{l}2-\text { medium and } \\
\text { high price strategy } \\
\text { (neutral strategy) }\end{array}$ & \\
\hline $\begin{array}{l}\text { Fotos } \\
\text { (3; II) }\end{array}$ & $\begin{array}{l}1 \text { - discriminatory } \\
\text { price strategy; } \\
2 \text { - flexible } \\
\text { (elastic) price } \\
\text { strategy }\end{array}$ & $\begin{array}{l}1 \text { - provides for the establishment of high prices for the consumers that are extremely } \\
\text { interested in buying the product; } \\
2 \text { - provides for the establishment of prices the level of which depends on the state of } \\
\text { the market's dynamics }\end{array}$ \\
\hline $\begin{array}{l}\text { Mobilluck } \\
(1,9 ; \mathrm{I})\end{array}$ & $\begin{array}{l}1-\text { - "psychological" } \\
\text { price strategy }\end{array}$ & $\begin{array}{l}1 \text { - provides for the establishment of prices that are somewhat lower that the "round" } \\
\text { amount, which creates a psychological impression of a lower price. Psychologists have } \\
\text { proven that consumers better accept the prices that end with "7" or "9" }\end{array}$ \\
\hline $\begin{array}{l}\text { Foxtrot } \\
(1 ; \mathrm{I})\end{array}$ & $\begin{array}{l}1 \text { - competitive } \\
\text { price strategy }\end{array}$ & $\begin{array}{l}1 \text { - provides for the establishment of prices that are lower than that of the competitors. } \\
\text { The seller, trying to establish a monopolistic position or increase the market share, sets } \\
\text { the prices that are lower than the average market value. }\end{array}$ \\
\hline
\end{tabular}

Thus, we have examined the relationship between the level of performance of the TOP-5 pricing management functions of the retail e-commerce companies and the marketing pricing objectives set, taking into account the risks and opportunities of the macro environment that affect the deficiencies and advantages of the micro environment.

Having been ranked by the above example, the results of the $\mathrm{S}$-analysis and the ranking of marketing distribution strategies of the TOP-5 retail electronic trade enterprises in Ukraine have been analyzed (Table 4).

Table 4. Marketing distribution strategies of the TOP-5 retailers in Ukraine (proposed by the authors)

\begin{tabular}{|c|c|c|}
\hline $\begin{array}{l}\text { Online } \\
\text { shop }\end{array}$ & $\begin{array}{c}\text { Marketing distribution } \\
\text { strategies }\end{array}$ & Distribution strategy peculiarities \\
\hline $\begin{array}{l}\text { Rozetka } \\
(3,2 ; \text { III })\end{array}$ & $\begin{array}{l}1-\text { product line } \\
\text { specialization strategy; } \\
2 \text { - selective } \\
\text { development strategy }\end{array}$ & $\begin{array}{l}1 \text { - the enterprise's distribution activity is oriented towards certain product } \\
\text { line; } \\
2 \text { - the enterprise's distribution activity is oriented towards: searching for the } \\
\text { ways to obtain competitive advantages; investing funds into more profitable } \\
\text { products with less degree of risk; specializing in promising products. }\end{array}$ \\
\hline $\begin{array}{l}\text { Allo } \\
(2,9 ; \text { II })\end{array}$ & $\begin{array}{l}1 \text { - selective } \\
\text { specialization strategy; } \\
2 \text { - consumer retention } \\
\text { strategy }\end{array}$ & $\begin{array}{l}1 \text { - the criteria used in target market selection are as follows: profitability and } \\
\text { conformance to the enterprise's resources and capabilities; } \\
2 \text { - this strategy is characterized by various implementation conditions; the life } \\
\text { cycle of the enterprise should be taken into account. }\end{array}$ \\
\hline $\begin{array}{l}\text { Fotos } \\
(2,2 ; \mathrm{II})\end{array}$ & $\begin{array}{l}1 \text { - segment } \\
\text { specialization strategy; } \\
2-\text { consumer } \\
\text { involvement strategy }\end{array}$ & $\begin{array}{l}1 \text { - the enterprise's distribution activity is oriented towards satisfying various } \\
\text { needs of a singular market segment; } \\
2 \text { - this strategy is characterized by various conditions used to encourage } \\
\text { persistent consumers' demand depending on the enterprise's life cycle. }\end{array}$ \\
\hline $\begin{array}{l}\text { Mobilluck } \\
(1,9 ; \mathrm{I})\end{array}$ & $\begin{array}{l}1 \text { - segment } \\
\text { specialization strategy; } \\
2 \text { - development } \\
\text { strategy }\end{array}$ & $\begin{array}{l}1 \text { - the enterprise's distribution activity is oriented towards satisfying the needs } \\
\text { of a single consumer segment; } \\
2 \text { - the characteristic features of this strategy are as follows: strengthening } \\
\text { weak competitive positions; activization of measures directed at products' } \\
\text { promotion; rendering additional services; determination and allocation of } \\
\text { competitive advantages. }\end{array}$ \\
\hline $\begin{array}{l}\text { Foxtrot } \\
(1,9 ; \mathrm{I})\end{array}$ & $\begin{array}{l}1 \text { - full market coverage } \\
\text { strategy; } \\
2 \text { - marketing channels } \\
\text { optimization strategy }\end{array}$ & $\begin{array}{l}1 \text { - the enterprise's distribution activity is oriented towards satisfying the needs } \\
\text { of the whole market; } \\
2 \text { - this strategy is directed towards the curtailment of distribution channels } \\
\text { through the middlemen exclusion. }\end{array}$ \\
\hline
\end{tabular}

From Table 4 we can conclude that the marketing distribution strategies of the retailers should be oriented towards the maximum satisfaction of the online consumers' needs, which requires regular marketing research and marketing control.

Based on the obtained results, one can come to the conclusion that the companies pursuing a high-level promotion policy (Rozetka) should continue to apply supportive marketing strategies for promotion. Companies that do not pay enough attention to the promotion policy (Mobilluck, Foxtrot) should apply aggressive marketing strategies for promotion (Table 5). 
Table 5. Marketing promotion strategies of the TOP-5 electronic commerce retailers in Ukraine (proposed by the authors)

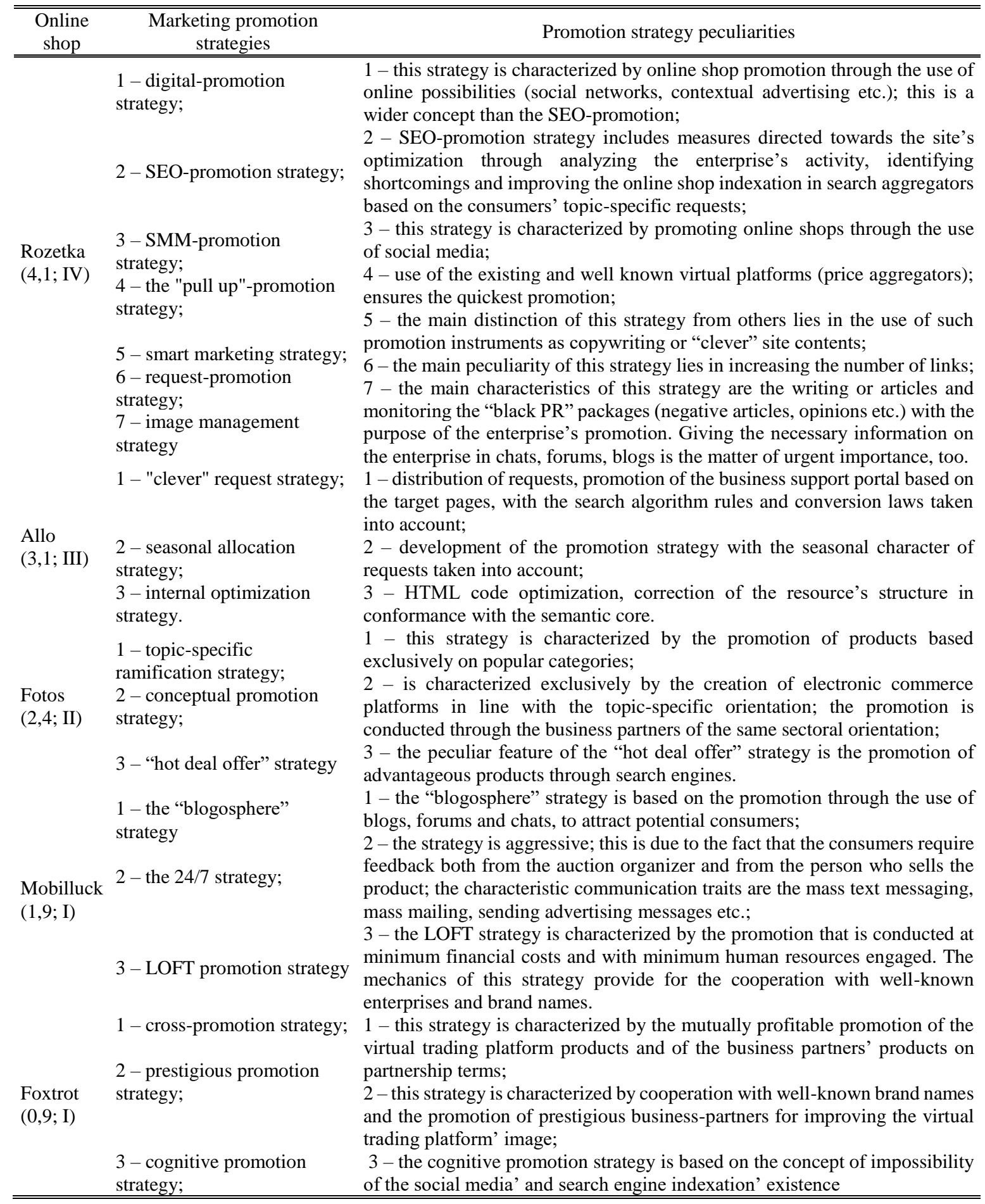

From Table 5 it is clear that marketing strategies for promotion of the retail e-commerce companies should be coordinated according to the values of enterprises, the disseminate trademark information and the form of a consumer loyalty system. The tools for influencing the consumers have changed over time; nowadays, it is not the stories of brand creation, but the provision of unique services that the public needs. The brand content is created in social networks and the measures are taken in accordance with a clear media plan. 


\section{CONCLUSION}

In the face of intense online market competition in times of a financial crisis, any company needs to use strategic marketing efforts aimed at quick market share capturing, the financial gain, the maximum brand recognition, and the favor on the side of online consumers.

The authors analyze the marketing strategies of the retail e-commerce companies. The data for the TOP-5 retail e-commerce enterprises of Ukraine have been analyzed and systematized based on the analysis performed with the use of the benchmarking method and of the SWOT-analysis. The proposed method for the marketing goals evaluation is the S-analysis, which allows to analyze the level of the marketing management function implementation, the level of threats and the macro environment capabilities, according to the deficiencies and advantages of the microenvironment. Via S-analysis it is possible to analyze the level of marketing management at the e-commerce companies, taking into account the external and internal environment. Knowing the weaknesses and strengths of e-commerce companies that are in a benchmark it's help avoid mistakes to install CRM-systems or gaining competitive advantages. The authors propose 4P strategies for businesses based on the deficiencies of e-commerce companies marketing management and weaknesses. $\mathrm{S}$-analysis can be introduced into the practical activity of the enterprise or implemented in automatic enterprise management systems.

\section{ACKNOWLEDGEMENT}

The main objective of the article is to assess the marketing strategies of the retail e-commerce enterprises in Ukraine - in particular, identifying the main challenges and problems of the industry. The methodological basis of the study includes the conceptual foundations of the marketing theory, the dialectical logic concept and the study of works by the Ukrainian and foreign scholars in the field of the online enterprises' marketing activity development, based on the strategic approach, the methodological basis of the study. To achieve this goal, the authors use the dialectical method of scientific knowledge and a number of general scientific and special research methods, interconnected and consistently applied in the general logic of analysis: the theoretical synthesis, the analysis and synthesis, the expert evaluation, the system analysis and the statistical analysis, as well as the economic and mathematical modeling etc.

\section{REFERENCES}

Dubovyk, T, Gamova I. (2018) International e-commerce. Bulletin of Uzhgorod National University. International Economic Relations and the World Economy Series. - Vol. 1 (17), pp. 51-55.

Fayvishenko, D. (2018). Formation of brand position strategy. Baltic Journal of Economic Studies. - Riga: Publishing Hous "Baltija Publishing". Vol. 4, No. 2, pp. 245-249.

Litovchenko, I. L. (2009). Методологічні аспекти інтернет-маркетингу: Монографія. [Methodological aspects of Internet-marketing: Monograph]. (196 p.). Naukova dumka, Kyiv, Ukraine.

Misnik, N. V. (2011). On-line shopping in Ukraine: opportunities and challenges. The Ukrainian Journal of Business Law. 9 (10), 29-33.

Romanenko, O. O. (2014). Types of Internet Marketing Strategies. Economics: realities of time. 6 (16), pp. 70-76.

Sana, M. (2009). Carlton Ads That Travel: Planning a Safe and Profitable Journey for Your Campaign. Retrieved from http://www.millwardbrown.com/Libraries/MB_POV_Downloads/Millward Brown_POV_AdsThatTravel.sflb.ashx.

Shuen, A. (2008). Web 2.0: A Strategy Guide: Business thinking and strategies behind successful Web 2.0 implementations. "O'Reilly Media, Inc.".

Sidora, T. Ү. (2012). Критерії оцінювання ефективності діяльності підприємства. [Criteria for evaluating the effectiveness of the enterprise]. Effective economy. Retrieved from http://www.economy.nayka.com.ua/?op=1\&z=1298.

The Ultimate Startup Marketing Strategy by Venture Harbour. (2015). Retrieved May 08, 2016, from https://www.ventureharbour.com/ultimate-startupmarketing-strategy.

Рейтинг интернет-магазинов уанета: Топ-100 компаний по обороту. (2018). [The rating of online stores Uanet: Top 100 companies by turnover]. Forbes Ukraine. Retrieved from http://forbes.ua. 